\title{
Pathological alpha-synuclein propagates through neural networks
}

\author{
Masami Masuda-Suzukake1, Takashi Nonaka', Masato Hosokawa², Maki Kubo', Aki Shimozawa', \\ Haruhiko Akiyama ${ }^{2}$ and Masato Hasegawa ${ }^{1 *}$
}

\begin{abstract}
Background: a-Synuclein is the major component of filamentous inclusions that constitute the defining characteristic of Parkinson's disease, dementia with Lewy bodies and multiple system atrophy, so-called a-synucleinopathies. Recent studies revealed that intracerebral injection of recombinant a-synuclein fibrils into wild-type mouse brains induced prion-like propagation of hyperphosphorylated a-synuclein pathology. However, the propagation mechanisms of a-synuclein have not been fully elucidated.
\end{abstract}

Results: In this study, in order to establish where and how a-synuclein pathology propagates, we injected recombinant mouse a-synuclein fibrils into three different brain areas (substantia nigra, striatum, and entorhinal cortex) of wild-type mice and compared the resulting distributions of a-synuclein pathology at 1 month after injection. Distinct patterns of pathology were observed in mice injected at the different sites. Within one month after injection, the pathology had spread to neurons in areas far from the injection sites, especially areas with direct neural connections to the injection sites. Surprisingly, phosphorylated tau and TDP-43 pathologies were also observed in mice injected with a-synuclein fibrils into striatum and entorhinal cortex at one month after injection. Phosphorylated tau and TDP-43 were accumulated in dot-like inclusions, but these were rarely colocalized with a-synuclein pathology. It seems that accumulation of a-synuclein has a synergistic effect on tau and TDP-43 aggregation. Additionally, intracerebral injection with sarkosyl-insoluble fraction prepared from wild-type mice injected synthetic a-synuclein fibrils can also induce phosphorylated a-synuclein pathology in wild-type mice.

Conclusions: Our data indicate that a-synuclein aggregation spread by prion-like mechanisms through neural networks in mouse brains.

Keywords: a-Synuclein, Lewy bodies, Propagation, Prion

\section{Introduction}

Parkinson's disease (PD) and dementia with Lewy bodies (DLB) are progressive neurodegenerative diseases characterized by appearance of Lewy bodies (LBs) and Lewy neurites (LNs) [1]. $\alpha$-Synuclein ( $\alpha$ syn) is the major component of LBs and LNs, and is deposited in a hyperphosphorylated form in $\beta$-sheet-rich amyloid fibrils [2-5]. Five missense mutations in the asyn gene and occurrence of gene multiplication have been identified in the familial forms of PD and DLB [6-13]. Moreover, it was reported that the mutations affect amyloid fibril formation in vitro,

\footnotetext{
* Correspondence: hasegawa-ms@igakuken.or.jp

${ }^{1}$ Department of Neuropathology and Cell Biology, Tokyo Metropolitan Institute of Medical Science, 2-1-6 Kamikitazawa, Setagaya-ku, Tokyo 156-0057, Japan

Full list of author information is available at the end of the article
}

either accelerating fibril formation [14-16] or resulting in formation of fibrils that are more fragile and easy to propagate than wild-type (WT) fibrils [17]. These results clearly indicate that abnormalities of asyn can induce PD and DLB. Distribution of asyn pathology in brains with sporadic PD occurs from olfactory bulb and/or brainstem, and spreads to other brain regions concomitantly with progression of disease symptoms $[18,19]$. Thus, spread of asyn pathology in the brain can be regarded as the underlying mechanism of progression of these diseases. Recently intracerebral injection of synthetic asyn fibrils and/or insoluble $\alpha$ syn from diseased brain was shown to induce asyn pathology that propagated throughout the brain in a prion-like manner in WT mouse [20,21], asyn transgenic mouse [22-24] and monkey [25]. However, the mechanisms through which exogenous abnormal fibrils enter 
neurons and through which insoluble $\alpha$ syn is transported to other neurons remain unknown.

To investigate where $\alpha$ syn pathologies develop and how they propagate, we injected recombinant $\alpha$ syn fibrils into substantia nigra, striatum, or entorhinal cortex of WT mice, and compared the spreading patterns and distribution of phosphorylated asyn pathologies at 1 month after intracerebral injections. Our results clearly suggest that propagation of pathological $\alpha$ syn occurred along neural circuits and involved trans-synaptic transport. We also showed that asyn pathology induced tau and TDP-43 accumulation in WT mice, similar to that seen in DLB brains. This mouse model should be useful for elucidating mechanisms of disease progression of synucleinopathy and also for development of novel disease-modifying drugs.

\section{Materials and methods}

\section{Antibodies}

Antibodies used in this study are summarized in Additional file 1: Table S1. 1175 polyclonal antibody was raised against an $\alpha$ syn peptide phosphorylated at serine 129 [21,26]. Antiphosphorylated asyn mouse monoclonal antibody, \#64 [5] and anti-human $\alpha$ syn specific mouse monoclonal antibody, LB509 [27] were kindly provided from Dr. Iwatsubo.
Rabbit polyclonal pS396 antibody (Calbiochem) is specific for phosphorylated tau at serine 396; biotin-AT8 (Thermo Scientific) is specific for phosphorylated tau at serine 202/ threonine 205; anti-mouse $\alpha$ syn rabbit monoclonal antibody (Cell Signaling Technology) is specific for mouse asyn. Rabbit polyclonal pTDP-43 antibody is specific for phosphorylated at serine 409/410 [28].

\section{Preparation of recombinant asyn monomer and fibrils}

Mouse $\alpha$ syn cDNA in bacterial expression plasmid pRK172 was used. $\alpha$ Syn were expressed in Escherichia coli BL21 (DE3) cells and purified using boiling, Q-sepharose ion exchange chromatography and ammonium sulfate precipitation. Purified asyn protein was dialyzed against $30 \mathrm{mM}$ Tris- $\mathrm{HCl}, \mathrm{pH} \mathrm{7.5}$, and cleared using ultracentrifugation at $113,000 \mathrm{~g}$ for $20 \mathrm{~min}$. Protein concentration was determined by reverse phase HPLC. Proteins were loaded on an Aquapore RP-300 column (PerkinElmer Brownlee) equilibrated in $0.09 \%$ trifluoroacetic acid with linear gradient of acetonitrile 0 to $50 \%$ at a flow rate of $1 \mathrm{ml} / \mathrm{min}$ [21]. Purified mouse asyn monomer (7 mg/ml) in $30 \mathrm{mM}$ Tris- $\mathrm{HCl}$, $\mathrm{pH} 7.5$, containing $0.1 \% \mathrm{NaN}_{3}$ was incubated at $37^{\circ} \mathrm{C}$ in a shaking incubator at $200 \mathrm{rpm}$ for $72 \mathrm{~h}$. $\alpha$ Syn fibrils were pelleted by spinning at 113,000 g for $20 \mathrm{~min}$ and

A
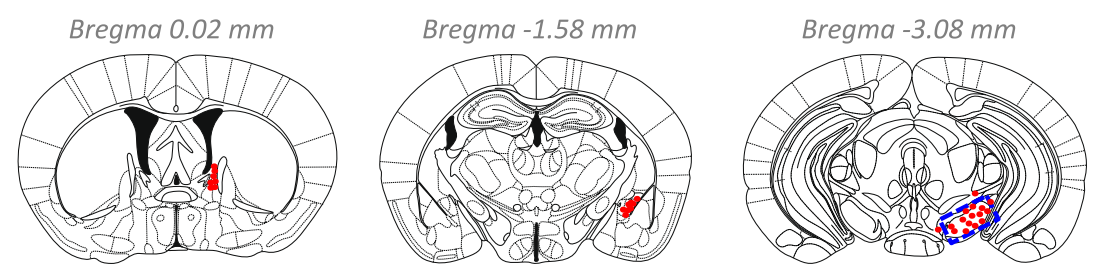

B
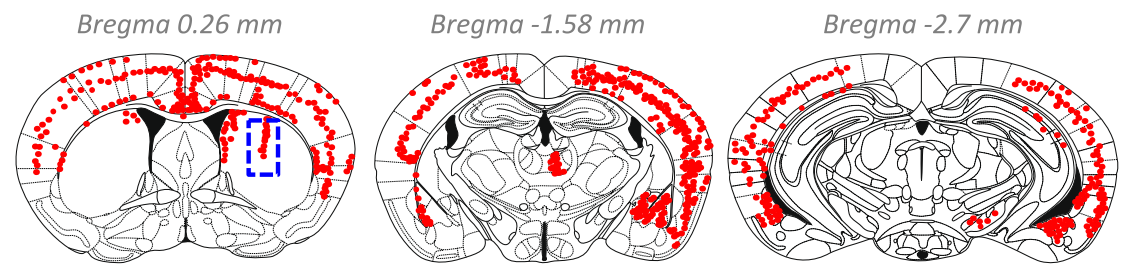

C
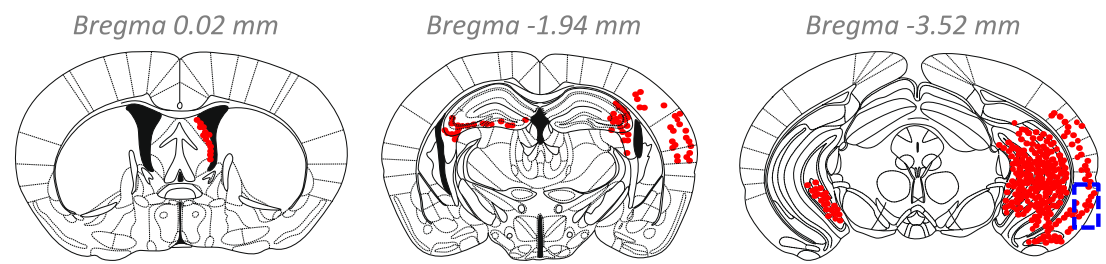

Figure 1 Distribution of phosphorylated asyn pathology in asyn fibril-injected mice at 1 month after injection. (A) Injection into SN induced asyn pathology mainly in SN (3.08 mm posterior to bregma), amygdala (1.58 $\mathrm{mm}$ posterior to bregma) and stria terminalis (0.02 $\mathrm{mm}$ anterior to bregma). (B) Injection into Str induced severe asyn pathology throughout the brain, including Str (0.26 mm anterior to bregma), amygdala (1.58 mm posterior to bregma), SN (2.70 mm posterior to bregma) and a wide range of cortex. (C) Injection into EC induced asyn pathology that was concentrated in EC (3.52 mm posterior to bregma), dentate gyrus ( $3.52 \mathrm{~mm}$ posterior to bregma), CA3 (3.52 mm posterior to bregma), fimbria (1.94 $\mathrm{mm}$ posterior to bregma), and septal nucleus (0.02 $\mathrm{mm}$ anterior to bregma). Blue-dashed box and red dots indicate the injection site and psyn pathology, respectively. 
suspended in PBS. $\alpha$ Syn fibrils were sonicated with a ultrasonic homogenizer (VP-5S, TAITEC) before use. To determine the concentration, fibrils were dissolved in $8 \mathrm{M}$ guanidine hydrochloride and analyzed by RPHPLC as described above.

\section{Mice}

C57BL/6 J mice, used as WT mice, were purchased from CLEA Japan, Inc. $\alpha$ Syn (SNCA) knockout mice [29] were purchased from the Jackson Laboratory.

\section{Stereotaxic surgery}

Four- to six-month-old mice anesthetized with $50 \mathrm{mg} /$ $\mathrm{kg}$ pentobarbital sodium were unilaterally injected with $10 \mu \mathrm{g}$ of recombinant mouse $\alpha$ syn fibrils into substantia nigra (SN, $\mathrm{n}=6)(\mathrm{A}-\mathrm{P}:-3.0 \mathrm{~mm}$; M-L: $-1.3 \mathrm{~mm}$; D-V: -4.7 $\mathrm{mm}$ from the bregma and dura) [21], striatum (Str, $\mathrm{n}=6$ ) (A-P: $0.2 \mathrm{~mm}$; M-L: $-2.0 \mathrm{~mm}$; D-V: $-2.6 \mathrm{~mm}$ ) [20], or entorhinal cortex (EC, $\mathrm{n}=6)(\mathrm{A}-\mathrm{P}:-3.1 \mathrm{~mm}$; M-L: $-4.0 \mathrm{~mm}$; $\mathrm{D}-\mathrm{V}$ : $-2.7 \mathrm{~mm})$. Mice were anesthetized with isoflurane and killed by decapitation. For immunohistochemistry (IHC, $\mathrm{n}=3$ ), brains were fixed in $10 \%$ formalin neutral buffer solution (Wako). For biochemical analysis $(n=3)$, brains were snap-frozen on dry ice and stored at $-80^{\circ} \mathrm{C}$. All experimental protocols were approved by the Animal
Care and Use Committee of the Tokyo Metropolitan Institute of Medical Science.

\section{Peripheral injection of asyn}

For intraperitoneal injection, 2-month-old C57BL/6 J mice were injected intraperitoneally with $100 \mu \mathrm{g}$ of mouse $\alpha$ syn monomer or fibrils. At 6 months after injection, the pathology of mouse brains in both groups ( $n=3$ each) was tested by immunohistochemistry (IHC). For oral administration, 2- or 3-month-old C57BL/6 J mice were orally administrated with $400 \mu \mathrm{g}$ of human $\alpha$ syn monomer, human asyn fibrils, mouse $\alpha$ syn monomer or mouse $\alpha$ syn fibrils every two weeks for 4 times. At 12 months post final administration, pathology in mouse brains ( $n=3$ each) was analyzed by IHC.

\section{Immunohistochemistry}

Fixed brains were cut on a vibratome (Leica) at $50 \mu \mathrm{m}$ thickness. For high-sensitivity detection, mouse brain sections were treated with formic acid for $30 \mathrm{~min}$, washed, and boiled at $100^{\circ} \mathrm{C}$ for $30 \mathrm{~min}$. The sections were then incubated with $0.5 \% \mathrm{H}_{2} \mathrm{O}_{2}$ in methanol to inactivate endogenous peroxidases, blocked with $10 \%$ calf serum in PBS, and immunostained with appropriate antibodies. After incubation with the biotinylated-secondary antibody (Vector), labeling was detected using the $\mathrm{ABC}$ staining kit (Vector).
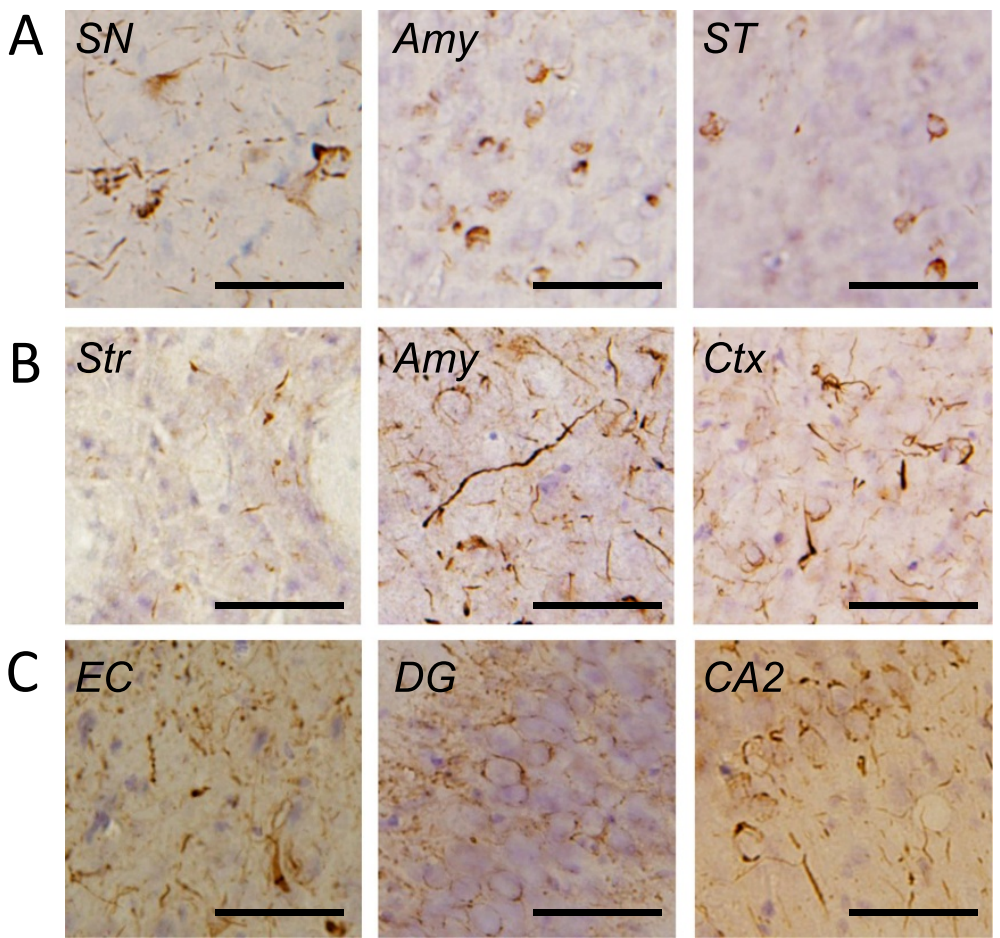

Figure 2 Staining of WT mouse brains injected with asyn fibrils at 1 month after injection by using 1175 antibody. (A) Psyn pathology in mice injected into SN. (B) Psyn pathology in mice injected into Str. (C) Psyn pathology in mice injected into EC. SN: substantia nigra, Amy: amygdala, ST: stria terminalis, Str: striatum, Ctx: cortex, EC: entorhinal cortex, DG: dentate gyrus. Scale bar represents $50 \mu \mathrm{m}$. 


\section{Confocal microscopy}

For double-label immunofluorescence to detect phosphorylated $\alpha$ syn and tau, brain sections were incubated overnight at $4^{\circ} \mathrm{C}$ in a cocktail of \#64 antibody and antipS396 antibody. The sections were washed and incubated in a cocktail of Alexa568-conjugated goat anti mouse IgG (Molecular Probes) and Alexa488-conjugated goat anti rabbit IgG (Molecular Probes). After further washing, sections were stained with TOPRO-3, coverslipped with Vectashield (Vector) and observed with a laser-scanning confocal fluorescence microscope (LSM5 PASCAL; Carl Zeiss).

\section{Biochemical analysis}

Biochemical analysis of mouse brains ( $n=3$ per group) was conducted as described previously [21]. Briefly, brains were homogenized in 20 volumes $(\mathrm{w} / \mathrm{v})$ of buffer A (10 mM Tris-HCl, pH 7.4, $0.8 \mathrm{M} \mathrm{NaCl}, 1$ mM EGTA and $10 \%$ sucrose), then spun at $100,000 \mathrm{~g}$ for $30 \mathrm{~min}$ at $4^{\circ} \mathrm{C}$, and the supernatant was retained as buffer-soluble

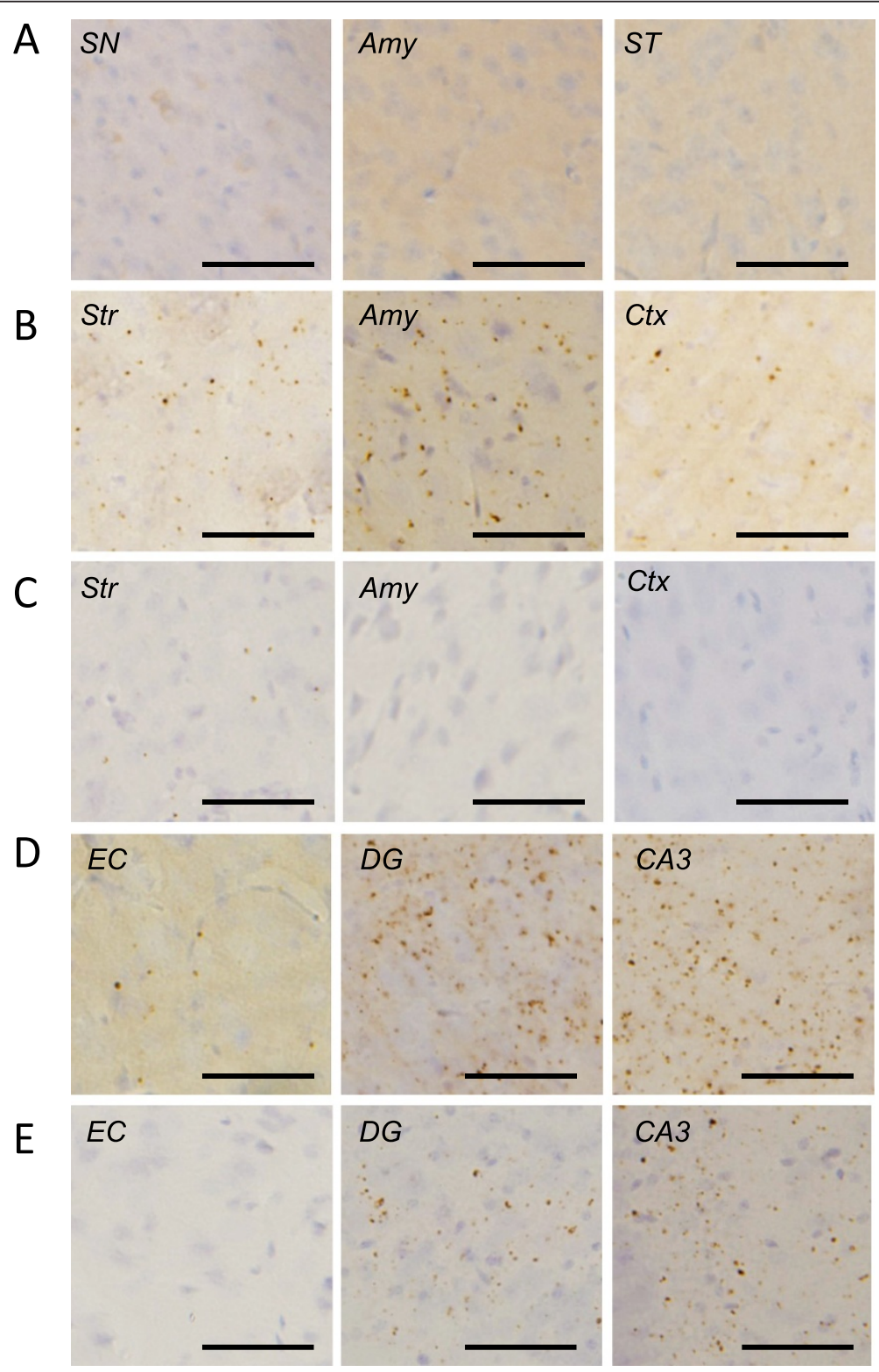

Figure 3 Induction of phosphorylated tau inclusions in WT mice injected with asyn fibrils at 1 month after injection. (A) Phosphorylated tau was not accumulated in mice injected into SN, based on staining with anti-pS396 antibody. (B-C) Dot-like tau inclusions were observed in mice injected into Str by using anti-pS396 antibody (B) and AT8 (C) (D-E). Dot-like tau inclusions were also detected in mice injected into EC by using anti-pS396 antibody (D) and AT8 (E). SN: substantia nigra, Amy: amygdala, ST: stria terminalis, Str: striatum, Ctx: cortex, EC: entorhinal cortex, DG: dentate gyrus. Scale bar represents $50 \mu \mathrm{m}$. 
fraction. The pellet was homogenized in 20 volumes of buffer A containing 1\% Triton X-100 and incubated for $30 \mathrm{~min}$ at $37^{\circ} \mathrm{C}$. After centrifugation at $100,000 \mathrm{~g}$, the Triton-insoluble pellet was further homogenized in buffer A containing $1 \%$ sarkosyl and incubated at $37^{\circ} \mathrm{C}$ for $30 \mathrm{~min}$. Samples were spun at 100,000 g for $30 \mathrm{~min}$. The sarkosyl-pellet was sonicated in $30 \mathrm{mM}$ Tris- $\mathrm{HCl}, \mathrm{pH}$ 7.4, and used for immunoblotting as sarkosyl-insoluble fraction. The samples were subjected to SDS-PAGE and proteins were electrotransferred onto a polyvinylidene difluoride membrane, probed with appropriate antibodies and detected as described previously [21].

\section{Behavioral tests}

For behavioral tests, C57BL/6 J male mice were used. Mouse asyn fibrils $(10 \mu \mathrm{g})$ were injected into $\mathrm{SN}(\mathrm{n}=10)$, Str $(n=15)$, or EC $(n=14)$ of 3-month-old mice, and the same amount of mouse $\alpha$ syn monomer was injected into SN $(n=9), \operatorname{Str}(n=8)$, or EC $(n=8)$ of control mice. At 3 months after injection, motor and cognitive activities were evaluated as described below.

\section{Rotarod test}

Motor coordination and balance were measured in terms of performance on the rotarod. Mice were placed on 3-cm diameter rods and the speed of the rotation was increased from 0 to $40 \mathrm{rpm}$ over $5 \mathrm{~min}$. Latency to fall was recorded. Each mouse was tested three times and the average was used. Statistical analyses were performed using Student's $t$-test.

\section{Wire hang test}

Neuromuscular abnormalities were tested with the wire hang test. The mouse was placed on a wire cage lid, which was waved gently so that the mouse gripped the wire and then inverted. Latency to fall was recorded with a 300-sec cut-off time. The test was conducted three times and statistical analyses were performed using Student's $t$-test.

\section{Y-maze test}

The Y-maze apparatus (Muromachi kikai) consisted of three arms $(40 \mathrm{~cm} \times 3 \mathrm{~cm})$ made of grey plastic joined in the middle to form a Y shape. Mice were placed into one of the arms of the maze and allowed to freely explore the three arms for an 8-min session. Alternation between arms was recorded. The Y-maze test was conducted twice. Statistical analyses were performed using Student's $t$-test.
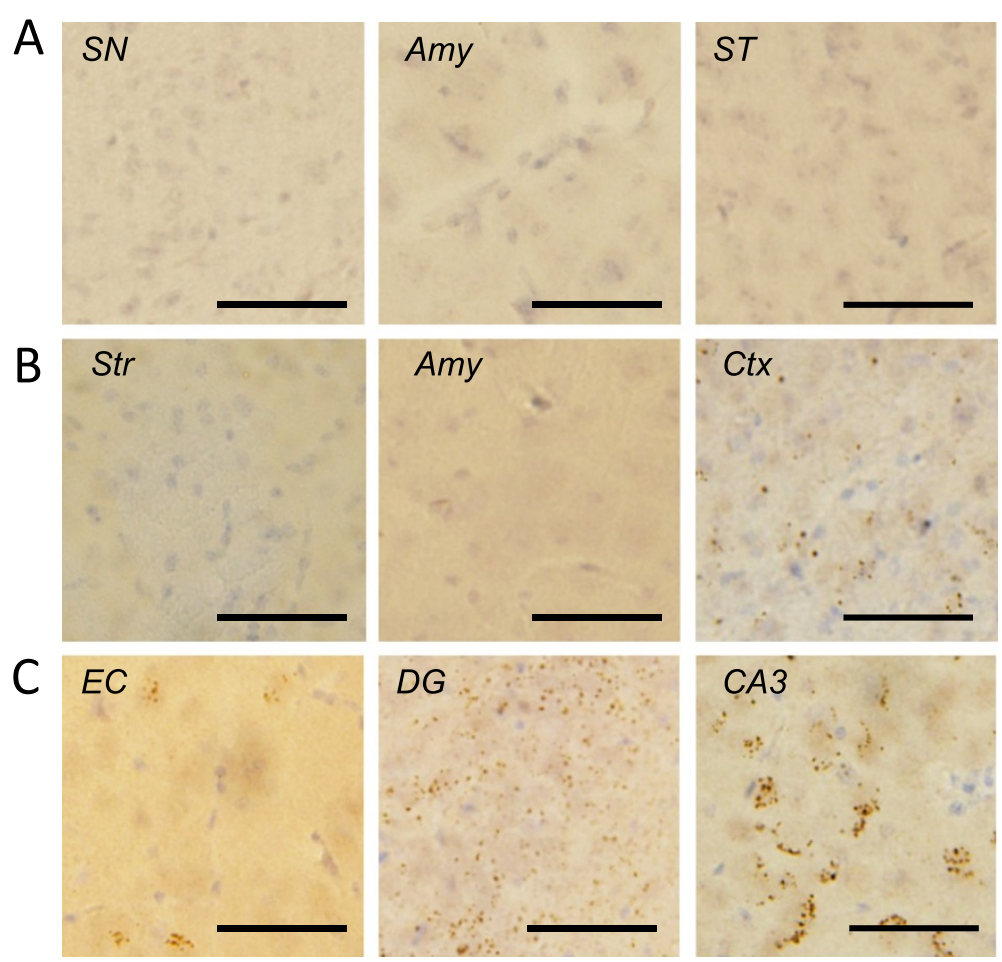

Figure 4 Induction of phosphorylated TDP-43-positive structures in WT mice injected with asyn fibrils at 1 month after injection.

(A) Phosphorylated TDP-43 was not accumulated in mice injected into SN, based on staining with anti-pS409/410 antibody. (B) Dot-like TDP-43 inclusions were observed in mice injected into Str. (C) Dot-like TDP-43 inclusions were also detected in mice injected into EC. SN: substantia nigra, Amy: amygdala, ST: stria terminalis, Str: striatum, Ctx: cortex, EC: entorhinal cortex, DG: dentate gyrus. Scale bar represents $50 \mu \mathrm{m}$. 


\section{Transmission experiments}

Recombinant human asyn fibrils $(10 \mu \mathrm{g})$ were injected into SN of 4-month-old WT mice $(n=4)$. At 9 months after injection, sarkosyl-insoluble pellets were prepared from the whole brains as described above, collected in one tube, and stored at $-80^{\circ} \mathrm{C}$ until use. Sarkosyl-insoluble pellets were suspended in $100 \mu \mathrm{l}$ PBS and sonicated for 30 seconds (TAITEC, VP-5S), and 5- $\mu$ l aliquots were injected into Str of 4-month-old WT mice $(n=10)$. At 3 months post injection, pathology was analyzed by IHC.

\section{Results}

We investigated the spread of $\alpha$ syn pathology in brains of mice after unilateral injection of recombinant mouse asyn fibrils into SN, Str, or EC. We confirmed the purity of recombinant asyn monomer and fibrils used in this study; they didn't contain any contaminants (Additional file 1: Figure S1). Using highly sensitive immunohistochemistry (IHC) with anti-phosphorylated asyn (psyn) antibody 1175 , we evaluated $\alpha$ syn pathology in the brains at 1 month after injection. The distribution of $\alpha$ syn pathology observed in these mice is illustrated in Figure 1. In mice injected into SN (Figure 1A), abnormal psyn pathology was restricted mainly to $\mathrm{SN}(3.08 \mathrm{~mm}$ posterior to bregma), amygdala (1.58 $\mathrm{mm}$ posterior to bregma), and stria terminalis (0.02 $\mathrm{mm}$ anterior to bregma) of the hemisphere on the injection side. In these mice, psyn was accumulated in neurites and soma (Figure 2A). In mice injected into Str, psyn pathology was widely distributed bilaterally throughout the brain, including $\operatorname{Str}(0.26 \mathrm{~mm}$ anterior to bregma), amygdala (1.58 $\mathrm{mm}$ posterior to bregma), SN (2.70 $\mathrm{mm}$ posterior to bregma) and cortex (Figure 1B). Psyn pathology was accumulated mainly in neurites, and partly in soma (Figure 2B). Injection of $\alpha$ syn fibrils into EC induced severe psyn pathology in EC (3.52 $\mathrm{mm}$ posterior to bregma), dentate gyrus (3.52 $\mathrm{mm}$ posterior to bregma), hippocampal CA3 region (1.94 and 3.52 $\mathrm{mm}$ posterior to bregma), fimbria (1.94 $\mathrm{mm}$ posterior to bregma), and septal nuclei (0.02 $\mathrm{mm}$ anterior to bregma) on the injection side, as well as moderate psyn pathology in hippocampus on the contralateral side (Figure 1C). Psyn pathology was mainly observed in neurites and perinuclear regions (Figure $2 \mathrm{C}$ ). No such psyn accumulation was detected in $\alpha$ syn $\mathrm{KO}$ mice injected with $\alpha$ syn fibrils into Str (Additional file 1: Figure S2A). Thus, there are major differences among these mice in the development and spread of asyn pathologies, demonstrating that the propagation pattern depends upon the injection site.

To investigate whether other pathologies are also induced by the injection of $\alpha$ syn fibrils, we performed IHC analysis using anti-tau, anti-TDP and anti-A $\beta$ antibodies. No tau pathology was observed in mice injected into SN
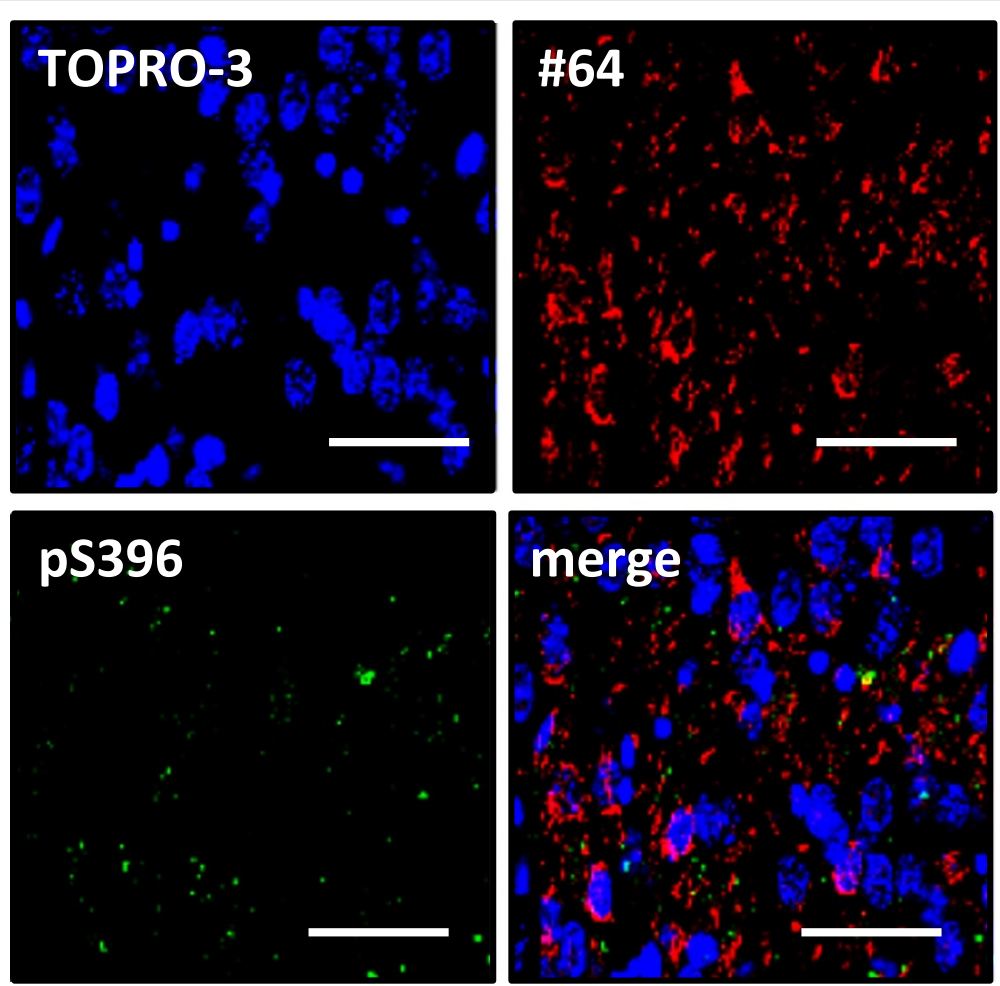

Figure 5 Dot-like ptau-positive structures showed little colocalization with psyn pathology in hippocampus of mice injected with asyn fibrils into EC at 1 month after injection. Brain sections were double-labeled with anti-psyn antibody (\#64, red) and anti-ptau antibody (pS396, green). Scale bar represents $50 \mu \mathrm{m}$ 
(Figure 3A). However, surprisingly, in mice injected into Str, pS396-positive dot-like structures were observed in Str, amygdala, and cortex (Figure 3B). Anti-phosphorylated tau (ptau) antibody AT8 also stained these structures in Str (Figure 3C). Similar ptau-positive dot-like structures were also observed with anti-pS396 antibody in EC, dentate gyrus and CA3 of the mice injected into EC, and were most frequent in CA3 (Figure 3D). Similar staining was observed in CA3 and dentate gyrus with AT8 antibody (Figure 3E). Furthermore, phosphorylated TDP-43 was also accumulated in mice injected into Str and EC (Figure 4B,C), although it was not detected in mice injected into SN (Figure 4A) at 1 month after injection. $A \beta$ pathology was never observed in $\alpha$ syn fibrilinjected mice, regardless of injection site (Additional file 1: Figure S3). The tau and TDP-43 pathologies differed from psyn pathology in both shape and localization; most psyn pathologies were not colocalized with ptau-positive structures and the overlap was small (Figure 5).

To confirm the accumulation of these proteins and to analyze them biochemically, we next investigated sarkosylinsoluble fractions of these mice brains at 3 months after injection into SN, Str or EC (Figure 6). Sarkosyl-insoluble psyn was detected in both the right and left hemispheres of all these mice, though it was more abundant on the injection side. The accumulation was most abundant on the injection side (right brain) in mice injected into Str, and less abundant on the uninjected side in mice injected into SN or EC. The banding patterns of sarkosyl-insoluble psyn were identical among these mice, regardless of the injection site, and were indistinguishable from that of DLB brain (Figure 6 upper). Anti-mouse $\alpha$ syn antibody showed the same banding pattern as psyn antibody (Figure 6 middle). The 15, 22, 30 and $35 \mathrm{kDa}$ bands correspond to monomer, monoubiquitinated $\alpha$ syn, dimer and ubiquitinated dimer, respectively. Moreover, sarkosyl-insoluble ptau was detected in the right hemisphere of mice injected into Str, where the most abundant tau inclusions were observed (Figure 6 lower). On the other hand, asyn and tau accumulations were not observed in $\alpha$ syn $\mathrm{KO}$ mice injected with fibrils into Str (Additional file 1: Figure S4). These results indicate that inoculation of asyn fibrils converted mouse $\alpha$ syn at the injection sites to an abnormal form, that this change propagated from the injection site to the contralateral side of the brain, and that inoculation into Str also induced tau pathology.

Next, we analyzed motor and cognitive functions of these mice at 3 months after injection (Figure 7). Mice injected with $\alpha$ syn fibrils into SN and Str showed poorer performance on the rotarod test compared with control mice injected with soluble $\alpha$ syn (Figure 7A). Mice injected into $\mathrm{SN}$ also performed poorly on the wire hang test (Figure $7 \mathrm{~B}$ ). Cognitive dysfunction was not observed in any group in the Y-maze test (Figure 7C).

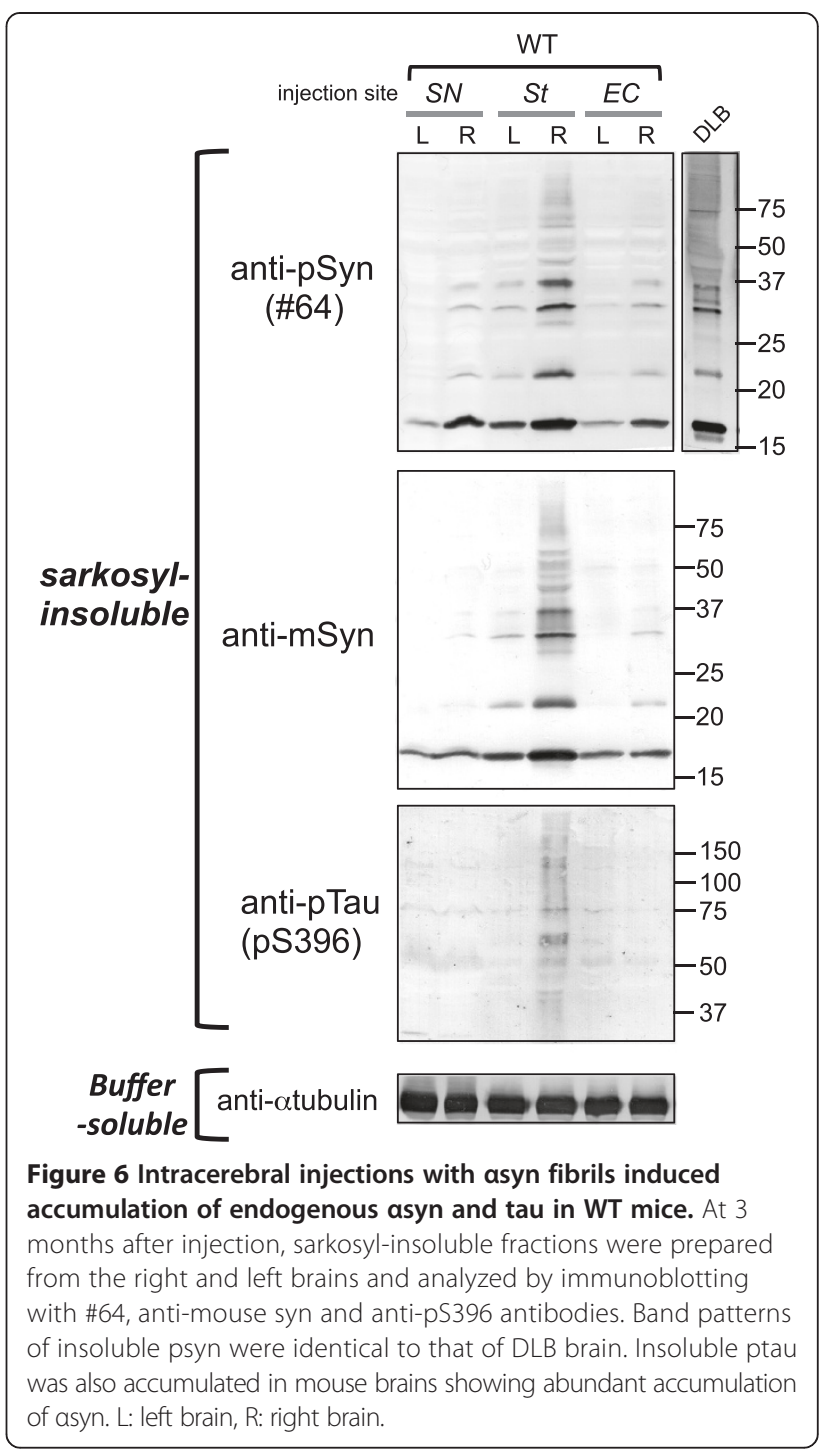

Finally, to examine whether insoluble $\alpha$ syn induced in WT mice shows prion-like propagation behavior, we assessed the transmissibility of insoluble $\alpha$ syn prepared from fibril-injected WT mouse brains. In brief, sarkosylinsoluble asyn was prepared from WT mouse brains injected with recombinant $\alpha$ syn fibrils and was injected into Str of other WT mouse brains (Figure 8A, B). Induction and propagation of psyn pathology were examined by IHC. At 3 months after injection, psyn pathology was observed in Str (0.26 mm anterior to bregma) and had also propagated to amygdala (1.46 $\mathrm{mm}$ posterior to bregma) and $\mathrm{SN}$ (3.08 $\mathrm{mm}$ posterior to bregma) (Figure $8 \mathrm{C}$ ). The distribution of psyn pathology is illustrated in Figure 8D. These data clearly showed that insoluble asyn derived from WT mice injected with asyn fibrils exhibits prionlike transmissibility. 

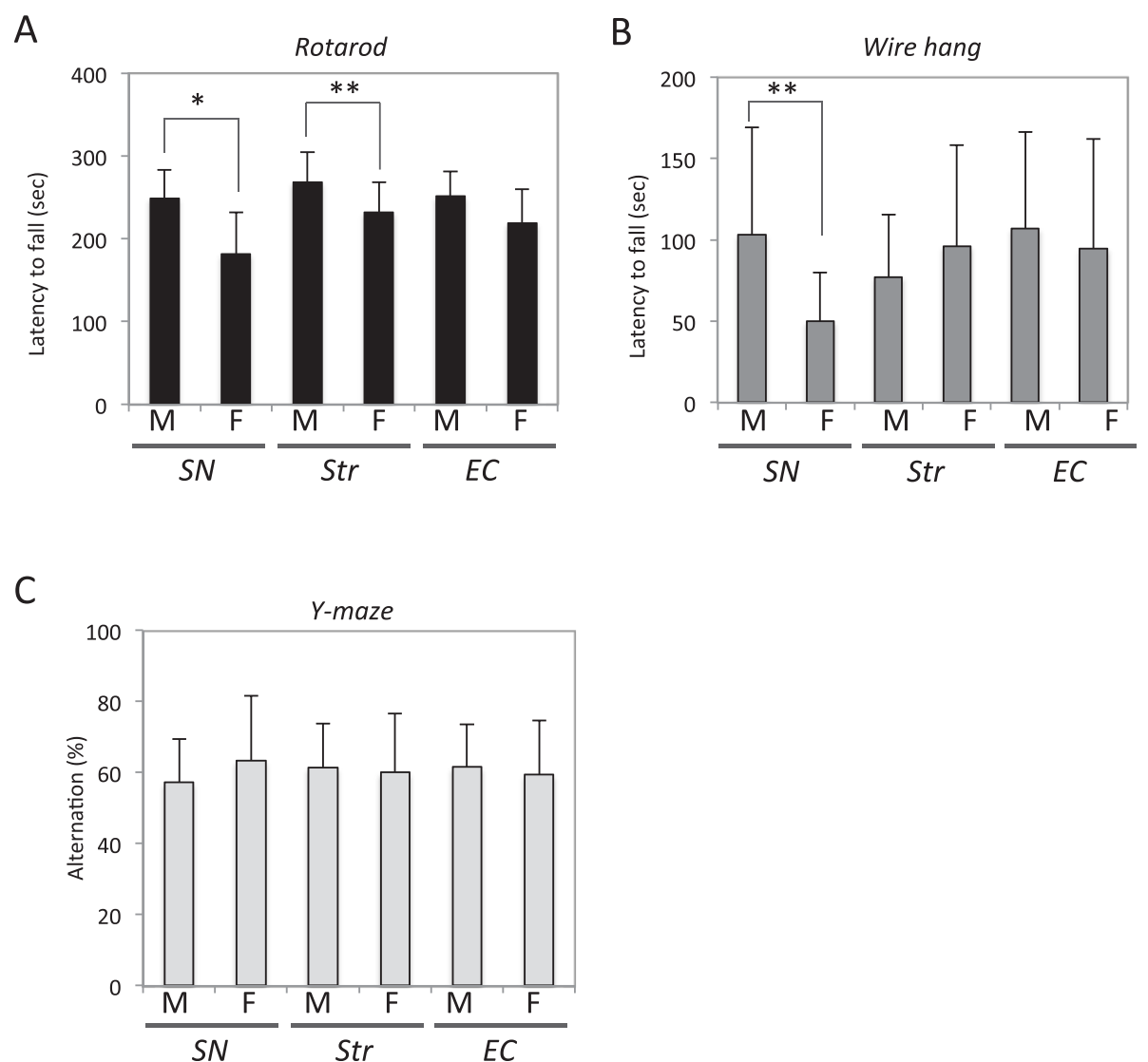

Figure 7 Fibril-injected mice showed motor dysfunctions compared to monomer-injected mice at 3 months after injection. (A) Rotarod test. Mice injected into SN and Str showed lower performance in the rotarod test. (B) Wire hang test. (C) Y-maze test. All error bars indicates mean \pm S. E. M. ${ }^{*} p<0.01,{ }^{* *} p<0.05$. M: asyn monomer-injected, F: asyn fibril-injected.

\section{Discussion}

Luk et al. and we have established that insoluble $\alpha$ syn shows prion-like propagation behavior in WT mouse brain $[20,21]$, but the mechanism of spreading remains poorly understood. In this study, we investigated the spread and distribution pattern of psyn pathology in mouse brain injected with recombinant $\alpha$ syn fibrils into three different brain regions: SN, Str, and EC. We assessed the distribution at 1 month post injection by using highly sensitive IHC. Pretreatment of brain sections with formic acid and heat enabled detection of psyn pathology at only 1 month after injection. When asyn fibrils were injected into SN, psyn pathology only appeared in the central nucleus of amygdala and stria terminalis, which are located far from $\mathrm{SN}$, while there was no detectable psyn pathology around $\mathrm{SN}$ (Figure 1A). Amygdala is connected with SN [30], and stria terminalis serves as a major output pathway of the central nucleus of amygdala. These findings strongly indicate that spreading of psyn pathology does not occur by simple diffusion or nonspecific transport. In the case of injection into Str, psyn pathology was observed in amygdala, SN and a wide range of cortices (Figure 1B). Str has direct projection to $\mathrm{SN}$ and amygdala [31], and many parts of the neocortex innervate the Str [32]. Injection into EC induced pathology in EC, dentate gyrus, hippocampal CA3, fimbria and septal nucleus (Figure 1C). Dentate gyrus receives projection from EC via the perforant pathway, and septal nucleus and fimbria have direct connections with hippocampus. Therefore, the data strongly suggest that propagation of pathological $\alpha$ syn occurs via axonal transport and a transsynaptic pathway, in accordance with reports that $\alpha$ syn fibrils can be internalized by neurons and transferred from axons to second-order neurons in culture [33] and in animal models $[34,35]$. In patients with sporadic PD, the distribution of Lewy bodies and Lewy neurites seems to spread retrogradely $[18,36]$. In the present study, focusing on Str and $\mathrm{SN}$, injection with $\alpha$ syn fibrils into Str induced $\alpha$ syn pathology in $\mathrm{SN}$ at 1 month after injection (Figure 1B). However, injection into SN did not induce pathology in Str at that time (Figure 1A), and pathology only became apparent in Str at 3 months after injection [21], indicating there is a dominant direction of spread. Propagation from EC to 


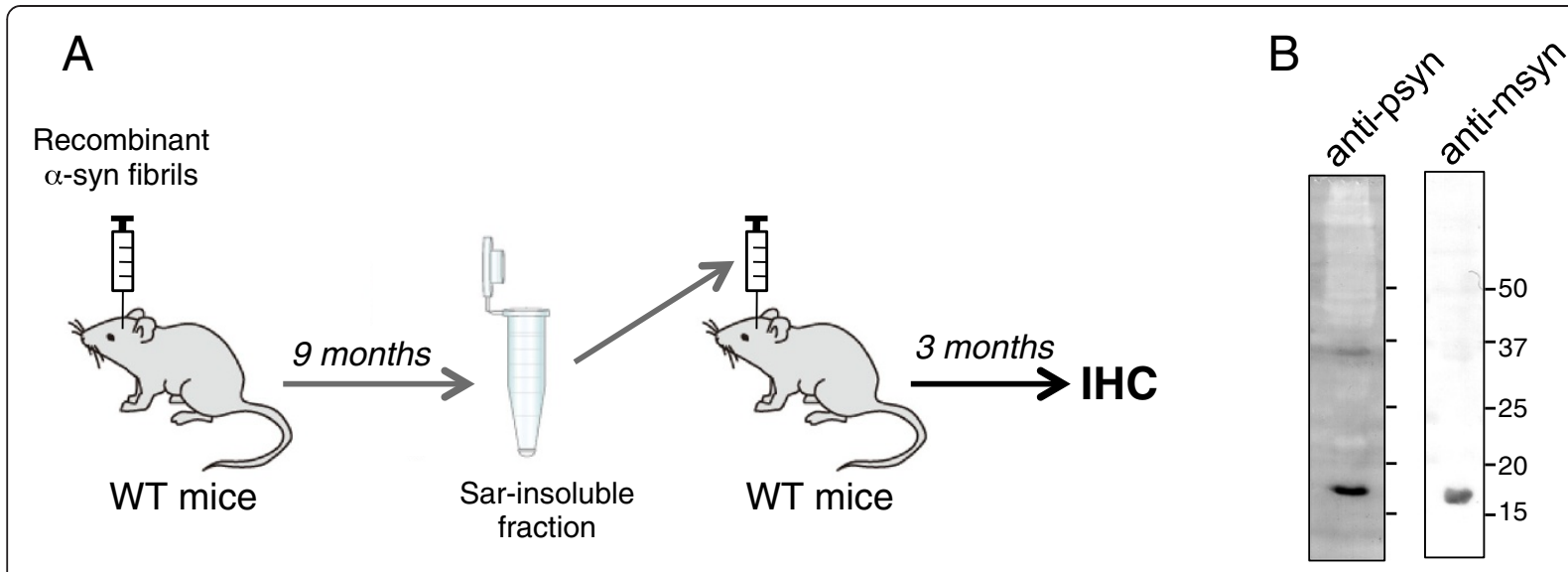

C striatum

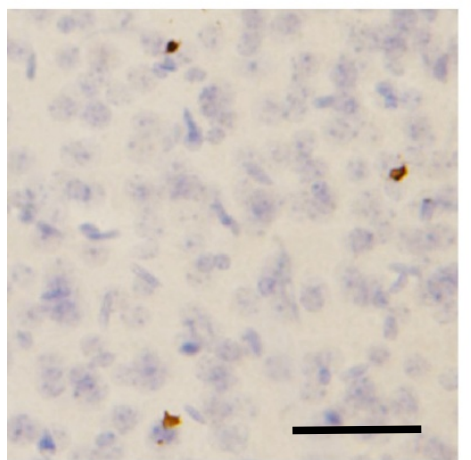

D Bregma $0.26 \mathrm{~mm}$

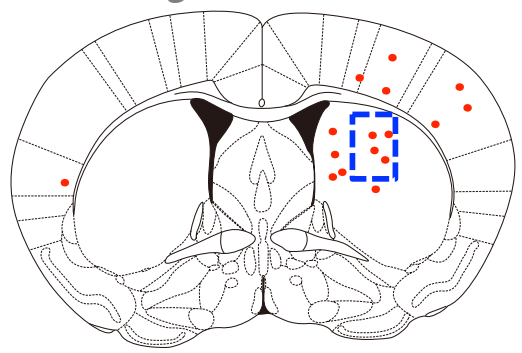

amygdala

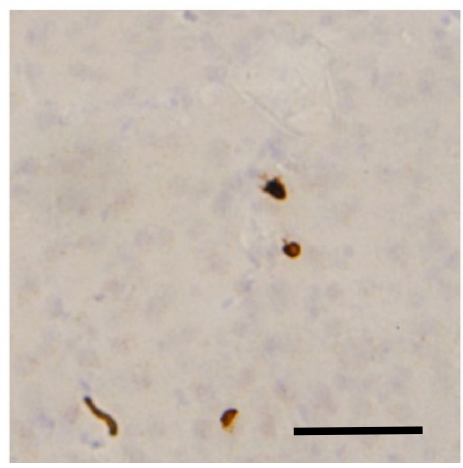

substantia nigra

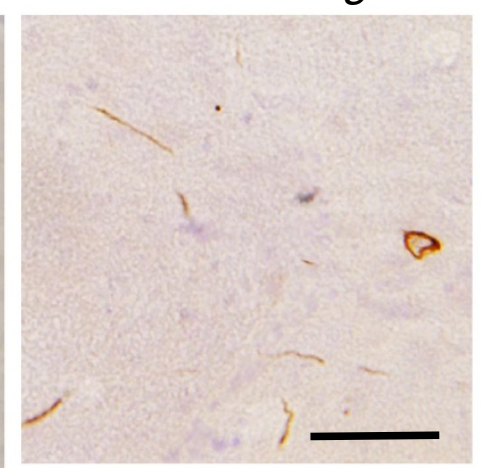

Figure 8 Sequential transmission of insoluble asyn. (A) Schematic diagrams of transmission experiments. Sarkosyl-insoluble fractions were prepared from WT mouse brains injected with recombinant asyn fibrils at 9 months post-injection and intracerebrally injected into 4-month-old WT mice. At 3 months after injection, transmission of asyn pathology was analyzed by IHC. (B) Immunoblot of sarkosyl-insoluble fractions from WT mice at 9 months post-injection with \#64 antibody and anti-msyn antibody. (C) Psyn pathology was observed mainly in Str, amygdala and SN with 1175 antibody. Scale bar represents $50 \mu \mathrm{m}$. (D) Distribution of psyn pathology in WT mouse brains injected with sarkosyl-insoluble fractions. Blue-dashed box and red dots indicate the injection site (Str) and psyn pathology, respectively.

dentate gyrus via the perforant pathway might occur via anterograde transport (Figure 1C). At least under our experimental conditions, propagation of $\alpha$ syn seems to occur via both anterograde and retrograde transport processes. Thus, the predominant direction of spread presumably depends on cell types or brain areas. Similarly, tau is also reported to propagate via a trans-synaptic pathway in animal models $[37,38]$. Thus, axonal transport and transsynaptic transport appear to be common pathways of propagation of intracellular aggregated proteins.

In addition, we found that tau and TDP-43 accumulation also occurred in WT mice injected with asyn fibrils 
into Str and EC at 1 month after injection (Figures 3B-E and 4). The morphological patterns of tau and TDP-43 accumulation were apparently different from that of $\alpha$ syn pathology (Figures 2, 3 and 4) and there was little colocalization (Figure 5), as in DLB brains $[39,40]$ and a DLB mouse model [41]. Recently, Guo et al. reported that there are two strains of recombinant $\alpha$ syn fibrils, strains $A$ and $B$, and the two strains differently affect tau inclusion formation [42]. They reported that strain A (preformed fibrils) only infrequently induced tau inclusions and psyn pathology showed little colocalization with tau inclusions, whereas strain B (generated through repetitively seeded fibrillization in vitro) efficiently induced tau inclusions that were highly colocalized in neurons. The $\alpha$ syn fibrils we used in this study are similar to strain A, and in agreement with their work [42], we also detected small amounts of tau inclusions that showed little colocalization with asyn pathology. In addition, tau accumulation was not observed in $\alpha$ syn $\mathrm{KO}$ mice injected with $\alpha$ syn fibrils by biochemical analysis (Additional file 1: Figure S4) or IHC (Additional file 1: Figure S2B). Thus, tau accumulation was induced by asyn accumulation, and this occurred through a synergistic effect rather than a cross-seeding effect. The tau accumulation might be caused by a secondary effect of $\alpha$ syn accumulation, such as dysfunction of cellular activity $[43,44]$ or abnormality in protein degradation machinery [45].

Biochemical analysis clearly showed that accumulated asyn was phosphorylated and ubiquitinated similarly to that in DLB brain, regardless of injection site (Figure 6). This indicates that injection with the same fibrils as seeds induces $\alpha$ syn aggregation in the same fashion, as is the case with prion strains.

Furthermore, $\alpha$ syn fibril-injected mice showed modest motor abnormalities compared to the monomer-injected mice at 3 months after injection (Figure 7). This strongly suggests that propagation of psyn pathology induced motor phenotypes, although we could not detect cognitive dysfunction in the Y-maze test. It is possible that this is because we injected $\alpha$ syn fibrils unilaterally, and the functions of the contralateral side of brain might be well maintained. In our previous study, we could not detect any abnormalities in fibril-injected mice at 6 months after injection [21]. The discrepancy may have arisen from differences in the test conditions, because in the previous study, we used female mice injected with human $\alpha$ syn fibrils, whereas in this study we used male mice injected with mouse asyn. Mouse asyn fibrils propagate more efficiently in WT mice than do human fibrils [21], and we think this was the main reason why we could detect motor abnormalities in the present study.

We next examined if insoluble $\alpha$ syn accumulated in WT mice shows transmissibility. Our results demonstrate that insoluble $\alpha$ syn accumulated in WT mice can induce $\alpha$ syn pathology in other WT mice (Figure $8 \mathrm{C}, \mathrm{D}$ ), analogously to prion transmission. We also examined intraperitoneal injection or oral administration with $\alpha$ syn fibrils into WT mice (see Materials and methods), but failed to detect any psyn pathology in the central nervous system at 6 months or 14 months after injection, respectively (data not shown).

\section{Conclusions}

Intracerebral injection with $\alpha$ syn fibrils into WT mouse brains enables to induce phosphorylated $\alpha$ syn pathology and the distribution of pathology depends on the injection sites. Furthermore, $\alpha$ syn pathology has a synergistic effect on tau and TDP-43 aggregation. We conclude that asyn fibrils have prion-like transmissibility and it might spread via axonal and trans-synaptic transports in mouse brains.

\section{Additional file}

\begin{abstract}
Additional file 1: Table S1. Antibodies used in this study. Figure S1. HPLC charts of recombinant mouse asyn used in this study. Mouse syn monomer showed only one peak that is derived from msyn monomer. Mouse syn fibril gave two peaks at 0.14 min (guanidine $\mathrm{HCl}$ ) and at 6.8 min (msyn fibril). Figure S2. aSyn and tau accumulation was never observed in fibril-injected asyn $\mathrm{KO}$ mice at 3 months after injection. (A) No psyn-positive pathology was observed with 1175 antibody. (B) Tau accumulation was not detected with pS396 antibody. Str: striatum, Amy: amygdala, SN: substantia nigra, sensory ctx: sensory cortex. Scale represents $50 \mu \mathrm{m}$. Figure S3. A $\beta$ accumulation was not observed in asyn fibril-injected WT mice at 1 month post injection. Sections were stained with anti-mouse $A \beta$ antibody. Mice injected into SN (A), Str (B), and EC (C). SN: substantia nigra, Amy: amygdala, ST: stria terminalis, Str: striatum, Ctx: cortex, EC: entorhinal cortex, DG: dentate gyrus. Scale represents $50 \mu \mathrm{m}$. Figure S4. Biochemical analysis of asyn $\mathrm{KO}$ mice injected with human asyn fibrils. The brain was divided into two parts at the longitudinal fissure of the cerebrum. Sarkosyl-insoluble fractions were obtained from the right and left brains, and analyzed by immunoblotting with \#64, LB509 or anti-mouse asyn antibodies. Exogenous human asyn fibrils were detected in sarkosyl-insoluble fractions and were not phosphorylated at 0 and 7 days after injection. They were subsequently degraded and disappeared within 30 days post injection. Phosphorylated asyn accumulation was never observed at 90 days after injection.
\end{abstract}

\section{Competing interests}

The authors declare that they have no competing interests.

\section{Authors' contributions}

MMS performed stereotaxic surgery, biochemical and IHC studies and wrote the manuscript. MK and AS performed IHC analysis and behavioral tests. TN and $\mathrm{MH}$ helped for interpretation of data. HA provided antibodies and helpful advice. $\mathrm{MH}$ performed study design and wrote the manuscript. All authors read and approved the final manuscript.

\section{Acknowledgements}

This work was supported by MEXT KAKENHI Grant Numbers 12937622, 12901980 (to M.H.), JSPS KAKENHI Grant Number 23700433 (to M.M-S.) and MHLW Grant Number 12946221 (to M.H.).

\section{Author details}

${ }^{1}$ Department of Neuropathology and Cell Biology, Tokyo Metropolitan Institute of Medical Science, 2-1-6 Kamikitazawa, Setagaya-ku, Tokyo 156-0057, Japan. ${ }^{2}$ Dementia Research Project, Tokyo Metropolitan Institute of Medical Science, Setagaya-ku, Tokyo, Japan 
Received: 14 July 2014 Accepted: 18 July 2014 Published: 6 August 2014

\section{References}

1. Goedert M (2001) Alpha-synuclein and neurodegenerative diseases. Nat Rev Neurosci 2(7):492-501, doi:10.1038/35081564

2. Spillantini MG, Schmidt ML, Lee VM, Trojanowski JQ, Jakes R, Goedert M (1997) Alpha-synuclein in Lewy bodies. Nature 388(6645):839-840, doi:10.1038/42166

3. Spillantini MG, Crowther RA, Jakes R, Hasegawa M, Goedert M (1998) AlphaSynuclein in filamentous inclusions of Lewy bodies from Parkinson's disease and dementia with lewy bodies. Proc Natl Acad Sci U S A 95(11):6469-6473

4. Baba M, Nakajo S, Tu PH, Tomita T, Nakaya K, Lee VM, Trojanowski JQ, Iwatsubo T (1998) Aggregation of alpha-synuclein in Lewy bodies of sporadic Parkinson's disease and dementia with Lewy bodies. Am J Pathol 152(4):879-884

5. Fujiwara H, Hasegawa M, Dohmae N, Kawashima A, Masliah E, Goldberg MS, Shen J, Takio K, Iwatsubo T (2002) Alpha-Synuclein is phosphorylated in synucleinopathy lesions. Nat Cell Biol 4(2):160-164, doi:10.1038/ncb748

6. Polymeropoulos MH, Lavedan C, Leroy E, Ide SE, Dehejia A, Dutra A, Pike B, Root H, Rubenstein J, Boyer R, Stenroos ES, Chandrasekharappa S, Athanassiadou A, Papapetropoulos T, Johnson WG, Lazzarini AM, Duvoisin RC, Di lorio G, Golbe LI, Nussbaum RL (1997) Mutation in the alpha-synuclein gene identified in families with Parkinson's disease. Science 276(5321):2045-2047

7. Kruger R, Kuhn W, Muller T, Woitalla D, Graeber M, Kosel S, Przuntek H, Epplen JT, Schols L, Riess O (1998) Ala30Pro mutation in the gene encoding alpha-synuclein in Parkinson's disease. Nat Genet 18(2):106-108, doi:10.1038/ng0298-106

8. Zarranz JJ, Alegre J, Gomez-Esteban JC, Lezcano E, Ros R, Ampuero I, Vidal L, Hoenicka J, Rodriguez O, Atares B, Llorens V, Gomez Tortosa E, Del Ser T, Munoz DG, de Yebenes JG (2004) The new mutation, E46K, of alpha-synuclein causes Parkinson and Lewy body dementia. Ann Neurol 55(2):164-173, doi:10.1002/ana.10795

9. Appel-Cresswell S, Vilarino-Guell C, Encarnacion M, Sherman H, Yu I, Shah B, Weir D, Thompson C, Szu-Tu C, Trinh J, Aasly JO, Rajput A, Rajput AH, Jon Stoessl A, Farrer MJ (2013) Alpha-synuclein p.H50Q, a novel pathogenic mutation for Parkinson's disease. Mov Disord 28(6):811-813, doi:10.1002/mds.25421

10. Lesage S, Anheim M, Letournel F, Bousset L, Honore A, Rozas N, Pieri L, Madiona K, Durr A, Melki R, Verny C, Brice A (2013) G51D alpha-synuclein mutation causes a novel parkinsonian-pyramidal syndrome. Ann Neurol 73(4):459-471, doi:10.1002/ana.23894

11. Singleton AB, Farrer M, Johnson J, Singleton A, Hague S, Kachergus J, Hulihan M, Peuralinna T, Dutra A, Nussbaum R, Lincoln S, Crawley A, Hanson M, Maraganore D, Adler C, Cookson MR, Muenter M, Baptista M, Miller D, Blancato J, Hardy J, Gwinn-Hardy K (2003) Alpha-Synuclein locus triplication causes Parkinson's disease. Science 302(5646):841, doi:10.1126/science.1090278

12. Chartier-Harlin MC, Kachergus J, Roumier C, Mouroux V, Douay X, Lincoln S, Levecque C, Larvor L, Andrieux J, Hulihan M, Waucquier N, Defebvre L, Amouyel P, Farrer M, Destee A (2004) Alpha-synuclein locus duplication as a cause of familial Parkinson's disease. Lancet 364(9440):1167-1169, doi:10.1016/S0140-6736(04)17103-1

13. Ibanez $P$, Bonnet AM, Debarges B, Lohmann E, Tison F, Pollak P, Agid $Y$, Durr A, Brice A (2004) Causal relation between alpha-synuclein gene duplication and familial Parkinson's disease. Lancet 364(9440):1169-1171, doi:10.1016/S0140-6736(04)17104-3

14. Conway KA, Harper JD, Lansbury PT (1998) Accelerated in vitro fibril formation by a mutant alpha-synuclein linked to early-onset Parkinson disease. Nat Med 4(11):1318-1320, doi:10.1038/3311

15. Choi W, Zibaee S, Jakes R, Serpell LC, Davletov B, Crowther RA, Goedert M (2004) Mutation E46K increases phospholipid binding and assembly into filaments of human alpha-synuclein. FEBS Lett 576(3):363-368, doi:10.1016/j. febslet.2004.09.038

16. Ghosh D, Mondal M, Mohite GM, Singh PK, Ranjan P, Anoop A, Ghosh S, Jha NN, Kumar A, Maji SK (2013) The Parkinson's disease-associated H50Q mutation accelerates alpha-Synuclein aggregation in vitro. Biochemistry 52(40):6925-6927, doi:10.1021/bi400999d

17. Yonetani M, Nonaka T, Masuda M, Inukai Y, Oikawa T, Hisanaga S, Hasegawa M (2009) Conversion of wild-type alpha-synuclein into mutant-type fibrils and its propagation in the presence of A30P mutant. J Biol Chem 284 (12):7940-7950, doi:10.1074/jbc.M807482200
18. Braak H, Del Tredici K, Rub U, de Vos RA, Jansen Steur EN, Braak E (2003) Staging of brain pathology related to sporadic Parkinson's disease. Neurobiol Aging 24(2):197-211

19. Attems J, Walker $L$, Jellinger KA (2014) Olfactory bulb involvement in neurodegenerative diseases. Acta Neuropathol 127(4):459-475, doi:10.1007/s00401-014-1261-7

20. Luk KC, Kehm V, Carroll J, Zhang B, O'Brien P, Trojanowski JQ, Lee VM (2012) Pathological alpha-synuclein transmission initiates Parkinson-like neurodegeneration in nontransgenic mice. Science 338(6109):949-953, doi:10.1126/science.1227157

21. Masuda-Suzukake M, Nonaka T, Hosokawa M, Oikawa T, Arai T, Akiyama H, Mann DM, Hasegawa M (2013) Prion-like spreading of pathological alphasynuclein in brain. Brain 136(Pt 4):1128-1138, doi:10.1093/brain/awt037

22. Mougenot AL, Nicot S, Bencsik A, Morignat E, Verchere J, Lakhdar $L$, Legastelois S, Baron T (2011) Prion-like acceleration of a synucleinopathy in a transgenic mouse model. Neurobiol Aging. doi:10.1016/j.neurobiolaging.2011.06.022

23. Luk KC, Kehm VM, Zhang B, O'Brien P, Trojanowski JQ, Lee VM (2012) Intracerebral inoculation of pathological alpha-synuclein initiates a rapidly progressive neurodegenerative alpha-synucleinopathy in mice. J Exp Med 209(5):975-986, doi:10.1084/jem.20112457

24. Watts JC, Giles K, Oehler A, Middleton L, Dexter DT, Gentleman SM, DeArmond SJ, Prusiner SB (2013) Transmission of multiple system atrophy prions to transgenic mice. Proc Natl Acad Sci U S A 110(48):19555-19560, doi:10.1073/pnas.1318268110

25. Recasens A, Dehay B, Bove J, Carballo-Carbajal I, Dovero S, Perez-Villalba A, Fernagut PO, Blesa J, Parent A, Perier C, Farinas I, Obeso JA, Bezard E, Vila M (2014) Lewy body extracts from Parkinson disease brains trigger alpha-synuclein pathology and neurodegeneration in mice and monkeys. Ann Neurol 75(3):351-362, doi:10.1002/ana.24066

26. Obi K, Akiyama H, Kondo H, Shimomura Y, Hasegawa M, Iwatsubo T, Mizuno Y, Mochizuki H (2008) Relationship of phosphorylated alpha-synuclein and tau accumulation to Abeta deposition in the cerebral cortex of dementia with Lewy bodies. Exp Neurol 210(2):409-420, doi:10.1016/j.expneurol.2007.11.019

27. Jakes R, Crowther RA, Lee VM, Trojanowski JQ, Iwatsubo T, Goedert M (1999) Epitope mapping of LB509, a monoclonal antibody directed against human alpha-synuclein. Neurosci Lett 269(1):13-16

28. Hasegawa M, Arai T, Nonaka T, Kametani F, Yoshida M, Hashizume Y, Beach TG, Buratti E, Baralle F, Morita M, Nakano I, Oda T, Tsuchiya K, Akiyama H (2008) Phosphorylated TDP-43 in frontotemporal lobar degeneration and amyotrophic lateral sclerosis. Ann Neurol 64(1):60-70, doi:10.1002/ana.21425

29. Abeliovich A, Schmitz Y, Farinas I, Choi-Lundberg D, Ho WH, Castillo PE, Shinsky N, Verdugo JM, Armanini M, Ryan A, Hynes M, Phillips H, Sulzer D, Rosenthal A (2000) Mice lacking alpha-synuclein display functional deficits in the nigrostriatal dopamine system. Neuron 25(1):239-252

30. Lee HJ, Gallagher M, Holland PC (2010) The central amygdala projection to the substantia nigra reflects prediction error information in appetitive conditioning. Learn Mem 17(10):531-538, doi:10.1101/Im.1889510

31. Smith AD, Bolam JP (1990) The neural network of the basal ganglia as revealed by the study of synaptic connections of identified neurones. Trends Neurosci 13(7):259-265

32. Gibb WR (1997) Functional neuropathology in Parkinson's disease. Eur Neurol 38(Suppl 2):21-25

33. Freundt EC, Maynard N, Clancy EK, Roy S, Bousset L, Sourigues Y, Covert M, Melki R, Kirkegaard K, Brahic M (2012) Neuron-to-neuron transmission of alpha-synuclein fibrils through axonal transport. Ann Neurol 72(4):517-524, doi:10.1002/ana.23747

34. Rey NL, Petit GH, Bousset L, Melki R, Brundin P (2013) Transfer of human alpha-synuclein from the olfactory bulb to interconnected brain regions in mice. Acta Neuropathol 126(4):555-573, doi:10.1007/s00401-013-1160-3

35. Ulusoy A, Rusconi R, Perez-Revuelta Bl, Musgrove RE, Helwig M, Winzen-Reichert B, Di Monte DA (2013) Caudo-rostral brain spreading of alpha-synuclein through vagal connections. EMBO Mol Med 5(7):1051-1059, doi:10.1002/emmm.201302475

36. Braak H, Rub U, Gai WP, Del Tredici K (2003) Idiopathic Parkinson's disease: possible routes by which vulnerable neuronal types may be subject to neuroinvasion by an unknown pathogen. J Neural Transm 110(5):517-536, doi:10.1007/s00702-002-0808-2

37. Liu L, Drouet V, Wu JW, Witter MP, Small SA, Clelland C, Duff K (2012) Trans-synaptic spread of tau pathology in vivo. PLoS One 7(2):e31302, doi:10.1371/journal.pone.0031302

38. Iba M, Guo JL, McBride JD, Zhang B, Trojanowski JQ, Lee VM (2013) Synthetic tau fibrils mediate transmission of neurofibrillary tangles in a 
transgenic mouse model of Alzheimer's-like tauopathy. J Neurosci 33(3):1024-1037, doi:10.1523/JNEUROSCI.2642-12.2013

39. Iseki E, Togo T, Suzuki K, Katsuse O, Marui W, de Silva R, Lees A, Yamamoto T, Kosaka K (2003) Dementia with Lewy bodies from the perspective of tauopathy. Acta Neuropathol 105(3):265-270, doi:10.1007/s00401-002-0644-3

40. Colom-Cadena M, Gelpi E, Charif S, Belbin O, Blesa R, Marti MJ, Clarimon J, Lleo A (2013) Confluence of alpha-synuclein, tau, and beta-amyloid pathologies in dementia with Lewy bodies. J Neuropathol Exp Neurol 72 (12):1203-1212, doi:10.1097/NEN.0000000000000018

41. Clinton LK, Blurton-Jones M, Myczek K, Trojanowski JQ, LaFerla FM (2010) Synergistic Interactions between Abeta, tau, and alpha-synuclein: acceleration of neuropathology and cognitive decline. J Neurosci 30(21):7281-7289, doi:10.1523/JNEUROSCI.0490-10.2010

42. Guo JL, Covell DJ, Daniels JP, Iba M, Stieber A, Zhang B, Riddle DM, Kwong LK, Xu Y, Trojanowski JQ, Lee VM (2013) Distinct alpha-synuclein strains differentially promote tau inclusions in neurons. Cell 154(1):103-117, doi:10.1016/j.cell.2013.05.057

43. Chung CY, Khurana V, Auluck PK, Tardiff DF, Mazzulli JR, Soldner F, Baru V, Lou Y, Freyzon Y, Cho S, Mungenast AE, Muffat J, Mitalipova M, Pluth MD, Jui NT, Schule B, Lippard SJ, Tsai LH, Krainc D, Buchwald SL, Jaenisch R, Lindquist $S$ (2013) Identification and rescue of alpha-synuclein toxicity in Parkinson patient-derived neurons. Science 342(6161):983-987, doi:10.1126/science.1245296

44. Volpicelli-Daley LA, Luk KC, Patel TP, Tanik SA, Riddle DM, Stieber A, Meaney DF, Trojanowski JQ, Lee VM (2011) Exogenous alpha-synuclein fibrils induce Lewy body pathology leading to synaptic dysfunction and neuron death. Neuron 72(1):57-71, doi:10.1016/j.neuron.2011.08.033

45. Nonaka T, Watanabe ST, Iwatsubo T, Hasegawa M (2010) Seeded aggregation and toxicity of \{alpha\}-synuclein and tau: cellular models of neurodegenerative diseases. J Biol Chem 285(45):34885-34898, doi:10.1074/jbc.M110.148460

doi:10.1186/s40478-014-0088-8

Cite this article as: Masuda-Suzukake et al:: Pathological alpha-synuclein propagates through neural networks. Acta Neuropathologica Communications $20142: 88$.

\section{Submit your next manuscript to BioMed Central and take full advantage of:}

- Convenient online submission

- Thorough peer review

- No space constraints or color figure charges

- Immediate publication on acceptance

- Inclusion in PubMed, CAS, Scopus and Google Scholar

- Research which is freely available for redistribution 